\title{
Copper incorporation in foraminiferal calcite: results from culturing experiments
}

\author{
L. J. de Nooijer ${ }^{1, *}$, G. J. Reichart ${ }^{1}$, A. Dueñas-Bohórquez ${ }^{1}$, M. Wolthers ${ }^{1}$, S. R. Ernst ${ }^{1}$, P. R. D. Mason ${ }^{1}$, and \\ G. J. van der Zwaan ${ }^{1}$ \\ ${ }^{1}$ Dept. of Earth Sciences, Utrecht University, Budapestlaan 4, 3584 CD Utrecht, The Netherlands \\ *now at: Institute for Research on Evolution of the Earth, Japan Agency for Marine Science and Technology (JAMSTEC), \\ 2-15 Natsushima-cho, 237-0061, Yokosuka, Japan
}

Received: 5 March 2007 - Published in Biogeosciences Discuss.: 2 April 2007

Revised: 2 July 2007 - Accepted: 2 July 2007 - Published: 10 July 2007

\begin{abstract}
A partition coefficient for copper $\left(\mathrm{D}_{\mathrm{Cu}}\right)$ in foraminiferal calcite has been determined by culturing individuals of two benthic species under controlled laboratory conditions. The partition coefficient of a trace element (TE) is an emperically determined relation between the TE/Ca ratio in seawater and the TE/Ca ratio in foraminiferal calcite and has been established for many divalent cations. Despite its potential to act as a tracer of human-induced, heavy metal pollution, data is not yet available for copper. Since partition coefficients are usually a function of multiple factors (seawater temperature, $\mathrm{pH}$, salinity, metabolic activity of the organism, etc.), we chose to analyze calcite from specimens cultured under controlled laboratory conditions. They were subjected to different concentrations of $\mathrm{Cu}^{2+}(0.1-20 \mu \mathrm{mol} / \mathrm{l})$ and constant temperature $\left(10\right.$ and $\left.20^{\circ} \mathrm{C}\right)$, seawater salinity and $\mathrm{pH}$. We monitored the growth of new calcite in specimens of the temperate, shallow-water foraminifer Ammonia tepida and in the tropical, symbiont-bearing Heterostegina depressa. Newly formed chambers were analyzed for $\mathrm{Cu} / \mathrm{Ca}$ ratios by laser ablation-ICP-MS. The estimated partition coefficient (0.1-0.4) was constant to within experimental error over a large range of $(\mathrm{Cu} / \mathrm{Ca})_{\text {seawater }}$ ratios and was remarkably similar for both species. Neither did the presence or absence of symbionts affect the $\mathrm{D}_{\mathrm{Cu}}$, nor did we find a significant effect of temperature or salinity on $\mathrm{Cu}$-uptake.
\end{abstract}

\section{Introduction}

Trace elements incorporated in foraminiferal calcite tests are widely used in paleoceanography: $\mathrm{Mg} / \mathrm{Ca}$ ratios are used to reconstruct sea surface (Nürnberg et al., 1996) and deep-sea

Correspondence to: L. J. de Nooijer

(nooijer@jamstec.go.jp) temperatures (Rathburn and DeDecker, 1997), Cd and Ba are used to estimate past seawater nutrient levels and alkalinity, respectively (Boyle, 1988; Rosenthal et al., 1997; Lea and Boyle, 1991). These proxies rely on empirically derived partition coefficients $\left(\mathrm{D}_{\mathrm{TE}}\right)$ and the dependence of these coefficients on environmental variables. Temperature is the main controlling factor a $\mathrm{D}_{\mathrm{TE}}$ in foraminiferal calcite, although salinity (Nürnberg et al., 1996) and TE/Ca ratios are also reported to affect the $\mathrm{D}_{\mathrm{TE}}$ (Segev and Erez, 2006).

Although field experiments are useful to determine first order proxy relationships, reliable proxy calibrations should include the contribution of so-called vital effects and separate the effects of other possible contributing factors. The best way to unravel the contribution of separate variables is through culturing experiments, in which one variable is varied and all the others are kept constant. In the case of some divalent cations (e.g. $\mathrm{Mg}^{2+}$ and $\mathrm{Sr}^{2+}$ : Nürnberg et al., 1996; Lea et al., 1999), culturing experiments also allow calibration of proxies out of the range of naturally occurring environmental conditions. This is important for trace elements that are associated with anthropogenic pollution with significantly raised concentrations above natural background levels.

Anthropogenic heavy metal pollution is often characterized by, amongst others, high $\mathrm{Cu}$-concentrations (Borrego et al., 2004; Sáinz and Ruiz, 2006). Foraminifera have been used in several ways to investigate environmental pollution as high levels of $\mathrm{Cu}$ and other heavy metals potentially deform foraminiferal chamber alignment and influence foraminiferal community stucture (Ellison et al., 1986; Samir and El-Din, 2001; Hallock et al., 2003; Armynot du Châtelet et al., 2004; Ruiz et al., 2004; Ferraro et al., 2006). However, a number of studies state that test deformations under high heavy metal concentrations occur less often than under

Published by Copernicus Publications on behalf of the European Geosciences Union. 

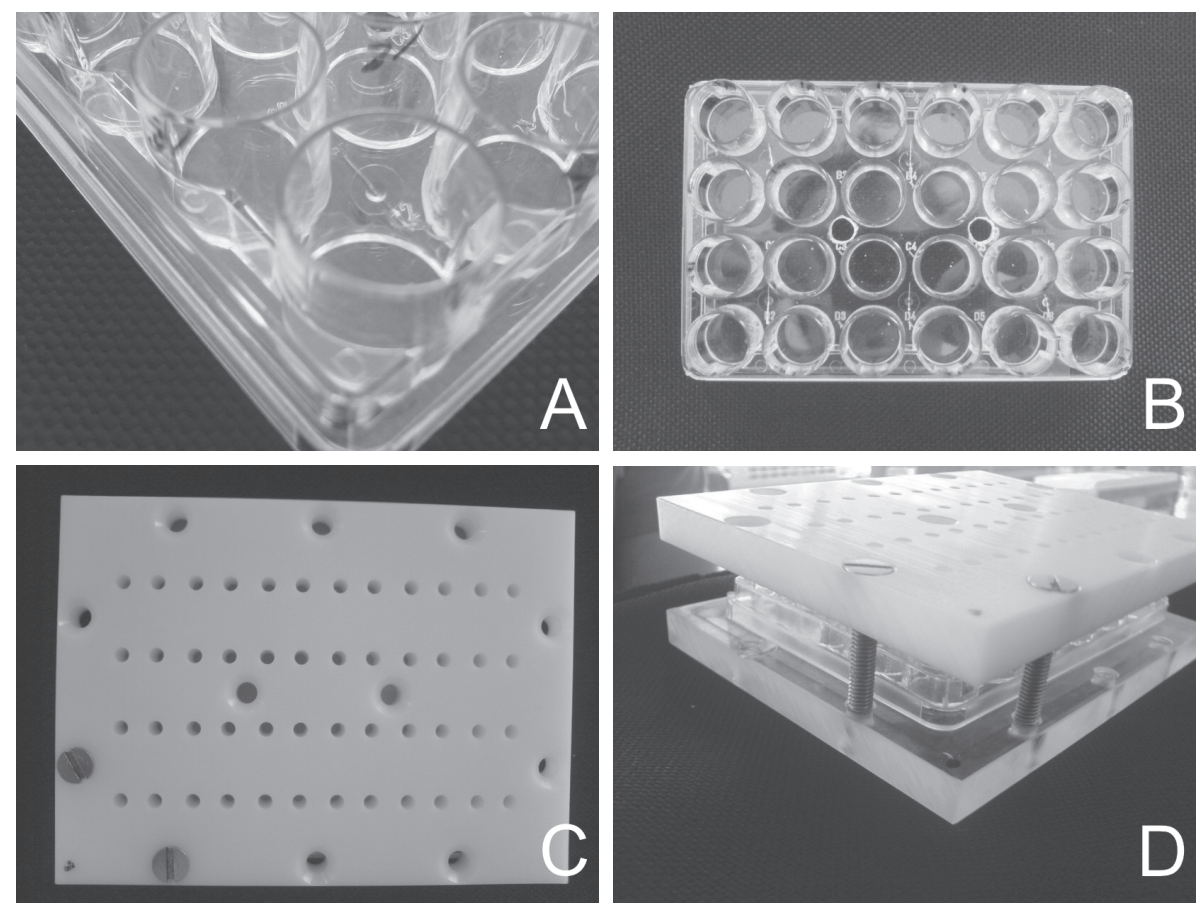

Fig. 1. Design of the experimental set-up. (A): close-up of a culture tray. (B): overview of a culture tray. (C) and (D): culture tray between plexiglass lids, with in- and outflow openings in upper lid.

medium pollution loads (Alve and Olsgard, 1999; Geslin et al., 2002; Le Cadre and Debenay, 2006). This suggests that reconstructions based on test deformations alone are not accurate.

In previous studies, $\mathrm{Cu}$ has been one of the most difficult elements to analyze in foraminiferal calcite (Boyle, 1981). However, recent advances in analytical methodology for trace element determination in foraminiferal calcite (Reichart et al., 2003) now enable the calibration of foraminiferal $\mathrm{Cu}$ to seawater chemistry for the first time, using cultured benthic foraminifera. Two different intertidal to neritic species (one temperate and one tropical) were cultured to establish possible interspecific differences in the partition coefficient of $\mathrm{Cu}$ in foraminiferal calcite.

\section{Methods}

\subsection{Collecting and culturing foraminifera}

Two similar culturing experiments were conducted in series. For the first experiment, sediment was collected at an intertidal flat in the Dutch Wadden Sea and was kept in the laboratory in the dark at $15^{\circ} \mathrm{C}$. Large $(>150 \mu \mathrm{m})$, living individuals of Ammonia cf. molecular type T6 (Hayward et al., 2004: further referred to as A. tepida) were transferred to our inhouse designed flow-through culture vessels (Fig. 1). Vessels consist of a 24-well culture tray, sandwiched between two Plexiglas plates and cells were connected by silicon tubes, attached with screws in the upper Plexiglas lid (Fig. 1). A small filter was placed between each cell and tube to prevent specimens from moving between cells. Trays were connected individually to a 2-liter reservoir with chemically altered seawater (see below) and a peristaltic pump was used to circulate seawater through the cells with a speed of $9 \mathrm{ml} / \mathrm{h}$ : in this way, six groups of 12 cells were formed, each connected to its own seawater reservoir. Four foraminiferal specimens were placed in each cell. Seawater was enriched with $\mathrm{Cu}$ from a stock solution at concentrations of $0,0.10,0.20,0.50$, 10 and $20 \mu \mathrm{mol} / \mathrm{l}$. Calcein (C0875, Sigma-Aldrich, St Louis, USA) was added to the $\mathrm{Cu}$-enriched seawater at a concentration of $5 \mathrm{mg} / \mathrm{l}$.

Calcein is incorporated into biogenic calcite, while existing calcite (i.e. earlier formed chambers) is not affected. Since (incorporated) calcein is fluorescent, foraminiferal chambers that have been built during the time when individuals were incubated can be recognized (Bernhard et al., 2004). Cells with specimens of Ammonia tepida, contained a thin layer $(<0.5 \mathrm{~mm})$ of artificial sediment (Silica, 52-63 $\mu \mathrm{m})$. Natural seawater from the eastern Mediterranean Sea was adjusted with MilliQ water to a salinity of 17 to mimic average Wadden Sea salinity. Salinity levels were regularly checked during the experiment with a WTW LF330 conductivity meter. All $6 * 12$ cells were kept at a constant temperature of $10^{\circ} \mathrm{C}$ for two months: before and after experiments, reservoirs were sub-sampled and seawater was analyzed by ICP$\mathrm{MS}$ for $\mathrm{Cu}, \mathrm{Mg}$ and $\mathrm{Ca}$. At the start of the incubation period, 
the individuals were fed $\sim 0.5 \mathrm{mg}$ of autoclaved $(20 \mathrm{~min}$ at $\left.121^{\circ} \mathrm{C}\right)$ Dunaliella sp. During experiments, the set-up was subjected to the daily sunlight cycle (app. $14 \mathrm{~h}$ light $/ 10 \mathrm{~h}$ dark).

For experiment 2 , trays were replaced and lids rigorously cleaned with $\mathrm{HCl}$, rinsed with MilliQ and re-used to incubate individuals of Heterostegina depressa in seawater with similar $\mathrm{Cu}$-enrichments used in the first experiments. H. depressa is an epibenthic, tropical and symbiont-bearing foraminifer, that was kept in our laboratory under high light intensities (15 W tropical reef lamp; Arcadia, FO15) and after transferring them into the culturing set-up, similar light conditions were maintained in a daily rhythm ( $14 \mathrm{~h}$ light/10 h dark). No sediment was added to the cells, seawater salinity was kept at 35 , with a constant temperature of $20^{\circ} \mathrm{C}$. Because of their large size, only two specimens were placed in each cell.

\subsection{Temperature and salinity of culture media}

For culturing Ammonia tepida, we diluted 35PSU seawater with MilliQ water to mimic intertidal ambient conditions with seawater of 17PSU. The dilution decreased both $\left[\mathrm{Ca}^{2+}\right]$ and $\left[\mathrm{CO}_{3}^{2-}\right]$ and the alkalinity by approximately $50 \%$, resulting in a pronounced reduction of the carbonate saturation state $(\Omega)$. The temperature maintained during these experiments was kept at $10^{\circ} \mathrm{C}$, compared to $20^{\circ} \mathrm{C}$ for the Heterostegina depressa experiments, allowing gas exchange with the atmosphere (ambient $\mathrm{pCO}_{2}$ ) in both cases. The combined effect of these changes is a reduction in saturation state from about 5.5 for the $H$. depressa experiment to about 1.0 for the A. tepida experiment (calculations were performed in CO2sys; Lewis and Wallace, 1998). The lower seawater saturation state for the A. tepida cultures was most likely responsible for the fact that newly formed chambers were thinner than the pre-experiment chambers (see Results).

\subsection{Laser ablation ICP-MS}

Newly formed chambers were ablated using an Excimer laser (Lambda Physik) with GeoLas 200Q optics inside a helium atmosphere flushed ablation chamber. Pulse repetition rate was set at $6 \mathrm{~Hz}$, with an energy density at the sample surface of $10 \mathrm{~J} / \mathrm{cm}^{2}$. Ablation craters were $60 \mu \mathrm{m}$ in diameter and ablated material was analyzed with respect to time (and hence depth) using a quadrupole ICP-MS instrument (Micromass Platform ICP).

Simultaneous monitoring of $\mathrm{Al}$ allowed us to discard the parts of the ablation profiles contaminated by clay minerals from further calculations of elemental concentrations. Since the analytical error increases with shorter ablation time we cleaned all specimens by an incubation of $24 \mathrm{~h}$ in $5 \% \mathrm{NaOCl}$ (Gaffey and Brönniman, 1993) before analysis, maximizing the amount of data that could be used for calculating $(\mathrm{Cu} / \mathrm{Ca})_{\text {calcite }}$ ratios.

\subsection{Calibration strategy}

The low calcite saturation state used in the experiment with Ammonia tepida resulted in formation of new chambers with thin walls. A similar correlation between test wall thickness and carbonate saturation state has been observed earlier for tests of cultured planktonic foraminifera (Bijma et al., 2002). Unfortunately, these thin chambers break easily during ablation when high laser energies are used. Therefore, we ablated Ammonia tepida with a laser energy of $1 \mathrm{~J} / \mathrm{cm}^{2}$, ten times less than the $10 \mathrm{~J} / \mathrm{cm}^{2}$ used to ablate newly formed chambers of Heterostegina depressa. Analyses were calibrated against NIST glasses 610 and 612, using concentration data of Pearce et al. (1997). Calibrating calcites against glasses is possible because of the relatively matrix independent ablation by the Excimer laser (Mason and Kraan, 2002). However, a fluence of $<2 \mathrm{~J} / \mathrm{cm}^{2}$ was close to the ablation threshold for glass and calibration was performed instead against matrix matched in-house standards (i.e. pressed calcite powder tablets). Calcium was used as an internal standard because (1) the concentration is constant at $40 \mathrm{wt} \%$ in calcite and (2) it allows direct comparisons with trace metal to $\mathrm{Ca}$ ratios from wet-chemical studies. A collision and reaction cell was used to give improved results by reducing spectral interferences on the minor isotopes of $\mathrm{Ca}\left({ }^{42} \mathrm{Ca},{ }^{43} \mathrm{Ca}\right.$ and ${ }^{44} \mathrm{Ca}$ : Mason and Kraan, 2002). Good agreement was observed when using both ${ }^{63} \mathrm{Cu}$ and ${ }^{65} \mathrm{Cu}$ isotopes to calculate $\mathrm{Cu}$ concentrations. Relative analytical precision for copper analyses was $15 \%$ on average, based on variability during the ablation calculated by GLITTER (New Wave Research, Fremont, CA, USA). This error includes both analytical uncertainties and internal, natural variability in test chemistry.

\subsection{Seawater $\mathrm{Cu}$-concentration}

The concentration of $\mathrm{Cu}$ did not vary considerably in most of our experiments during the experimental period across the range of concentrations used (Table 1).

In the first experiment, all measured $\mathrm{Cu}$-concentrations were lower than the target concentration and most total $\mathrm{Cu}-$ concentrations increased during the experiment, resulting in increased seawater $\mathrm{Cu} / \mathrm{Ca}$ ratios (on average $17 \%$ ). In experiment 2, most $\mathrm{Cu}$-concentrations and all $\mathrm{Cu} / \mathrm{Ca}$ ratios were higher at the start than at the end of the experiment. Identical procedures and techniques were used before and after subsampling the culture media, making it unlikely that sampling artifacts affected our measurements. Therefore, we used average solution $\mathrm{Cu} / \mathrm{Ca}$ ratios to estimate the partition coefficient of $\mathrm{Cu}$ in foraminiferal calcite and incorporated differences between start and end concentrations for uncertainty calculations. Error bars plotted in the different graphs are based on these calculations and largely stem from these changes, which are an order of magnitude larger than the analytical uncertainties. 
Table 1. Target concentrations of $\mathrm{Cu}$ in sea water and measured $[\mathrm{Cu}]_{\text {seawater }}$ and $(\mathrm{Cu} / \mathrm{Ca})_{\text {seawater }}$ at start and end of both experiments. $\mathrm{n} . \mathrm{a} .=$ not available.

\begin{tabular}{|c|c|c|c|c|c|}
\hline \multirow[t]{2}{*}{ Experiment } & \multirow{2}{*}{$\begin{array}{l}\text { Target }[\mathrm{Cu}] \\
\text { in } \mu \mathrm{mol} / 1\end{array}$} & \multicolumn{2}{|c|}{ Measured $\mathrm{Cu}$} & \multicolumn{2}{|c|}{$\mathrm{Cu} / \mathrm{Ca}$} \\
\hline & & $\begin{array}{l}\text { at the start of } \\
\text { experiment } \\
\text { in } \mu \mathrm{mol} / 1+1 \mathrm{SD}\end{array}$ & $\begin{array}{l}\text { at the end of } \\
\text { experiment } \\
\text { in } \mu \mathrm{mol} / 1+1 \mathrm{SD}\end{array}$ & $\begin{array}{l}\text { at start of } \\
\text { experiment } \times 10^{-6} \\
+1 \mathrm{SD} \times 10^{-6}\end{array}$ & $\begin{array}{l}\text { at end of } \\
\text { experiment } \times 10^{-6} \\
+1 \mathrm{SD} \times 10^{-6}\end{array}$ \\
\hline \multirow{5}{*}{$\begin{array}{l}\text { 1. Ammonia } \\
\text { tepida }\end{array}$} & 0 & 0.0843 & $0.100 \pm 0.00584$ & $6.32 \pm 5.28$ & $2.91 \pm 0.221$ \\
\hline & 0.10 & $0.0960 \pm 0.0146$ & n.a. & $2.95 \pm 0.384$ & n.a. \\
\hline & 0.50 & $0.332 \pm 0.00505$ & n.a & $10.1 \pm 0.0143$ & n.a. \\
\hline & 10 & $12.6 \pm 0.293$ & $14.0 \pm 0.867$ & $378 \pm 4.62$ & $408 \pm 6.94$ \\
\hline & 20 & $17.8 \pm 0.489$ & $20.0 \pm 3.05$ & $547 \pm 13.5$ & $473 \pm 20.8$ \\
\hline \multirow{2}{*}{$\begin{array}{l}\text { 2. Heterostegina } \\
\text { depressa }\end{array}$} & 0 & $0.125 \pm 0.00554$ & $0.208 \pm 0.0119$ & $1.69 \pm 0.0236$ & $3.62 \pm 0.343$ \\
\hline & 0.10 & $0.744 \pm 0.00217$ & $0.211 \pm 0.0408$ & $2.32 \pm 0.0670$ & $3.74 \pm 0.500$ \\
\hline
\end{tabular}

Table 2. Thermodynamic data for calcein (Ueno et al., 1992). $\mathrm{L}=$ calceine. ${ }^{\mathrm{a}}$ reactions leads to negligible metal binding; ${ }^{b}$ values extrapolated by assuming chemical behavior similar to $\mathrm{Cu}^{2+}$ (see text for discussion).

\begin{tabular}{|c|c|c|c|}
\hline & Reaction & Functional groups & $\log K$ \\
\hline (1) & $\mathrm{L}^{6-}+\mathrm{H}^{+}=\mathrm{HL}^{5-}$ & $-\mathrm{COOH}$ & 11.7 \\
\hline (2) & $\mathrm{HL}^{5-}+\mathrm{H}^{+}=\mathrm{H}_{2} \mathrm{~L}^{4-}$ & $-\mathrm{COOH}$ & 10.8 \\
\hline (3) & $\mathrm{H}_{2} \mathrm{~L}^{4-}+\mathrm{H}^{+}=\mathrm{H}_{3} \mathrm{~L}^{3-}$ & $-\mathrm{COOH}$ & 5.5 \\
\hline (4) & $\mathrm{H}_{3} \mathrm{~L}^{3-}+\mathrm{H}^{+}=\mathrm{H}_{4} \mathrm{~L}^{2-}$ & $-\mathrm{OH}$ & 4.2 \\
\hline (5) & $\mathrm{H}_{4} \mathrm{~L}^{2-}+\mathrm{H}^{+}=\mathrm{H}_{5} \mathrm{~L}^{-}$ & $\equiv \mathrm{NH}^{+}$ & 2.9 \\
\hline (6) & $\mathrm{H}_{5} \mathrm{~L}^{-}+\mathrm{H}^{+}=\mathrm{H}_{6} \mathrm{~L}$ & $\equiv \mathrm{NH}^{+}$ & 2.1 \\
\hline (7) & $2 \mathrm{Cu}^{2+}+\mathrm{L}^{6-}=\mathrm{Cu}_{2} \mathrm{~L}^{2-}$ & $-\mathrm{COOH}$ & 28.9 \\
\hline (8) & $\mathrm{Cu}^{2+}+\mathrm{H}_{2} \mathrm{~L}^{4-}=\mathrm{CuH}_{2} \mathrm{~L}^{2-}$ & $\equiv \mathrm{NH}^{+}$ & 8.3 \\
\hline (9) & $\mathrm{Cu}^{2+}+\mathrm{H}_{4} \mathrm{~L}^{2-}+\mathrm{H}_{3} \mathrm{~L}^{3-}=\mathrm{Cu}\left(\mathrm{H}_{4} \mathrm{~L}\right)\left(\mathrm{H}_{3} \mathrm{~L}\right)^{3-}$ & $-\mathrm{COOH}+-\mathrm{OH}$ & $10.4^{\mathrm{a}}$ \\
\hline (10) & $2 \mathrm{Ca}^{2+}+\mathrm{L}^{6-}=\mathrm{Ca}_{2} \mathrm{~L}^{2-}$ & $-\mathrm{COOH}$ & $27.2^{\mathrm{b}}$ \\
\hline (11) & $\mathrm{Ca}^{2+}+\mathrm{H}_{2} \mathrm{~L}^{4-}=\mathrm{CaH}_{2} \mathrm{~L}^{2-}$ & $\equiv \mathrm{NH}^{+}$ & 6.63 \\
\hline (12) & $\mathrm{Ca}^{2+}+\mathrm{H}_{4} \mathrm{~L}^{2-}+\mathrm{H}_{3} \mathrm{~L}^{3-}=\mathrm{Ca}\left(\mathrm{H}_{4} \mathrm{~L}\right)\left(\mathrm{H}_{3} \mathrm{~L}\right)^{3-}$ & $-\mathrm{COOH}+-\mathrm{OH}$ & $8.73^{\mathrm{a}, \mathrm{b}}$ \\
\hline (13) & $2 \mathrm{Mg}^{2+}+\mathrm{L}^{6-}=\mathrm{Mg}_{2} \mathrm{~L}^{2-}$ & $-\mathrm{COOH}$ & $28.5^{\mathrm{b}}$ \\
\hline (14) & $\mathrm{Mg}^{2+}+\mathrm{H}_{2} \mathrm{~L}^{4-}=\mathrm{MgH}_{2} \mathrm{~L}^{2-}$ & $\equiv \mathrm{NH}^{+}$ & 7.9 \\
\hline$(15)$ & $\mathrm{Mg}^{2+}+\mathrm{H}_{4} \mathrm{~L}^{2-}+\mathrm{H}_{3} \mathrm{~L}^{3-}=\mathrm{Mg}\left(\mathrm{H}_{4} \mathrm{~L}\right)\left(\mathrm{H}_{3} \mathrm{~L}\right)^{3-}$ & $-\mathrm{COOH}+-\mathrm{OH}$ & $10.0^{\mathrm{a}, \mathrm{b}}$ \\
\hline
\end{tabular}

\section{6 $\mathrm{Cu}$ speciation in seawater}

In the absence of organic matter, $\mathrm{Cu}$ in seawater forms mainly $\mathrm{Cu}(\mathrm{OH})_{2}$ and $\mathrm{CuCO}_{3}$, while small amounts of $\mathrm{Cu}^{2+}$ and $\mathrm{CuOH}^{-}$are also present (Zirino and Yamamoto, 1972). In natural seawater, however, usually more than $99.9 \%$ of the
$\mathrm{Cu}$ is bound to organic compounds (Eriksen et al., 2001), mainly in the colloidal state (Mackey and Zirino, 1994). Foraminifera take up organic particles and seawater by endocytosis, likely ingesting both free $\mathrm{Cu}$ and $\mathrm{Cu}$-ligand complexes. The internal routes that organic compounds follow are virtually uninvestigated in foraminifera and therefore, we 
Table 3. Added and free copper concentrations and activities in the experiments. Suffix $t=$ total copper concentration added to the experiment; suffix $c=$ corrected ratios (total $\mathrm{Cu}$ or $\mathrm{Ca}$ minus calceine-complexed $\mathrm{Cu}$ or $\mathrm{Ca}$ ).

\begin{tabular}{lllllll}
\hline Experiment & {$[\mathrm{Cu}]_{t}(\mu \mathrm{mol} / \mathrm{l})$} & $\{\mathrm{Cu}\}_{t}(\mu \mathrm{mol} / \mathrm{l})$ & {$[\mathrm{Cu}]_{t} /[\mathrm{Ca}]_{t}$} & {$[\mathrm{Cu}]_{c}(\mu \mathrm{mol} / \mathrm{l})$} & $\{\mathrm{Cu}\}_{c}(\mu \mathrm{mol} / \mathrm{l})$ & {$[\mathrm{Cu}]_{c} /[\mathrm{Ca}]_{c}$} \\
\hline 1. Ammonia tepida & 0.156 & 0.133 & $2.6 \times 10^{-5}$ & 0.156 & 0.133 & $2.6 \times 10^{-5}$ \\
& 0.168 & 0.146 & $2.9 \times 10^{-5}$ & 0.168 & 0.146 & $2.9 \times 10^{-5}$ \\
& 0.384 & 0.333 & $6.6 \times 10^{-5}$ & 0.384 & 0.333 & $6.6 \times 10^{-5}$ \\
& 1.05 & 0.911 & $18 \times 10^{-5}$ & 1.05 & 0.911 & $18 \times 10^{-5}$ \\
& 18.6 & 16.1 & $320 \times 10^{-5}$ & 18.6 & 16.1 & $320 \times 10^{-5}$ \\
& 38.0 & 32.9 & $660 \times 10^{-5}$ & 38.0 & 32.9 & $660 \times 10^{-5}$ \\
\hline 2. Heterostegina depressa & 0.167 & 0.140 & $1.6 \times 10^{-5}$ & 0.167 & 16 & $1.6 \times 10^{-5}$ \\
& 0.190 & 0.163 & $1.8 \times 10^{-5}$ & 0.190 & 18 & $1.8 \times 10^{-5}$ \\
& 0.255 & 0.218 & $2.4 \times 10^{-5}$ & 0.255 & 24 & 130 \\
& 1.36 & 1.16 & $13 \times 10^{-5}$ & 1.36 & $10 \times 10^{-5}$ & $13 \times 10^{-5}$ \\
& 12.1 & 10.3 & $110 \times 10^{-5}$ & 12.1 & 1100 & $110 \times 10^{-5}$ \\
\hline
\end{tabular}

do not know which $\mathrm{Cu}$ species are present at the site of calcification.

\subsection{Modelling $\mathrm{Cu}$ speciation}

The calcein added in our experiments is a ligand that can bind TE's and could thus cause concentrations of free $\mathrm{Cu}$ to drop. Traditionally, total calcium and TE concentrations in solution are used to calculate partition coefficients for TE's in calcite. Ideally, activities or effective concentrations, of relevant metals are used to allow application of partition coefficients in solutions of different compositions (Morse and Bender, 1990).

To correct for $\mathrm{Cu}$ binding to calcein, we calculated speciation of all abundant cations $(\mathrm{Cu}, \mathrm{Ca}$ and $\mathrm{Mg}$ ) in our solution. Speciation calculations were performed in PHREEQC 2.8.03 (Parkhurst and Appelo, 1999) with the llnl database and thermodynamic data for calcein listed in Table 2. For calcein complexation with calcium and magnesium, Reactions (11) and (14) are reported in the literature. These reactions will lead to competition between copper, calcium and magnesium in binding to an amine group on $\mathrm{H}_{2} \mathrm{~L}^{4-}$, thus decreasing calcein-bound $\mathrm{Cu}$. It is, therefore, likely that the behavior of $\mathrm{Ca}$ and $\mathrm{Mg}$ towards calcein is similar to $\mathrm{Cu}$ and similar competition between the three metals occurs in binding according to Reactions (7) and (9) via carboxyl groups ( $\mathrm{Lu}$ and Allen, 2002). Composition of the solution in the model was either the $\mathrm{Cu}$-enriched seawater with a salinity of 35 or of 17 for the experiment with Ammonia tepida, while both were open to atmospheric $\mathrm{CO}_{2}$.

$\mathrm{Cu}$ and $\mathrm{Ca}$-concentrations used to calculate the partition coefficients were those corrected for $\mathrm{Cu}$ and $\mathrm{Ca}$ complexated with calcein (Table 3 ).
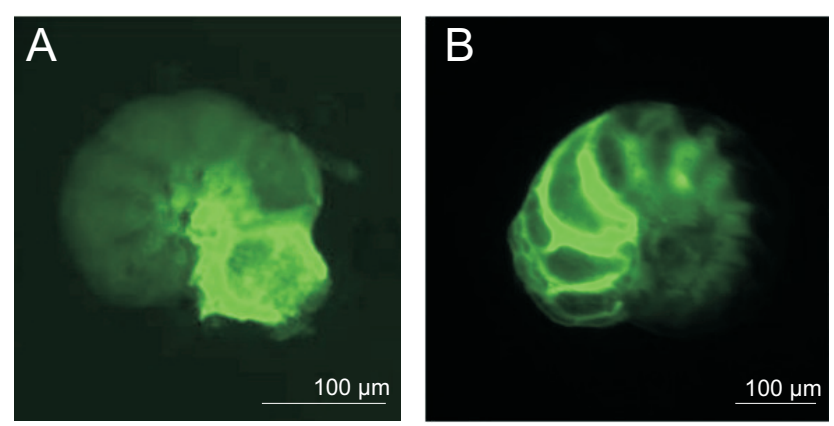

Fig. 2. New chambers added by Ammonia tepida (A) and Heterostegina depressa (B), visible by fluorescence of incorporated calcein.

\section{Results}

\subsection{New calcite and survival rates}

Specimens that grew new calcite were recognized by fluorescent, outer chambers (Fig. 2).

None of the individuals of Heterostegina depressa incubated at the target $\mathrm{Cu}$-concentration of $20 \mu \mathrm{mol} / 1$, survived the experimental period. At $10 \mu \mathrm{mol} / \mathrm{l}$ of added $\mathrm{Cu}$, however, several survived of which 1 individual grew new calcite. At lower concentrations, generally more chambers were formed (Table 4). None of the added chambers $(n=88)$ showed abnormal alignments or deformations.

For Ammonia tepida, the number of successful laserablation analyses was significantly lower (3) than the number of added chambers (34). The limited size $(<100 \mu \mathrm{m})$ of newly added chambers did not allow multiple analyses of a single chamber. After an unsuccessful attempt to analyze a targeted chamber it was not possible to repeat this measurement as the largest part of the carbonate was consumed (Fig. 3). 
Table 4. Number of individuals at the start of the experiments, number of specimens that formed new calcite and total number of added chambers.

\begin{tabular}{lcccc}
\hline Experiment & $\begin{array}{c}\text { Target }\left[\mathrm{Cu}^{2+}\right] \\
\text { in } \mu \mathrm{mol} / 1\end{array}$ & $\begin{array}{c}\text { Number of specimens } \\
\text { at start of experiment }\end{array}$ & $\begin{array}{c}\text { Number of individuals } \\
\text { that grew new chambers }\end{array}$ & $\begin{array}{c}\text { Number of new } \\
\text { chambers added }\end{array}$ \\
\hline 1. Ammonia tepida & 0 & 48 & 7 & 7 \\
& 0.10 & 48 & 11 & 12 \\
& 0.20 & 48 & 6 & 6 \\
& 0.50 & 48 & 3 & 5 \\
& 10 & 48 & 5 & 1 \\
\hline 2. Heterostegina depressa & 0 & 24 & 5 & 8 \\
& 0.10 & 24 & 3 & 0 \\
& 0.20 & 24 & 19 & 37 \\
\hline
\end{tabular}
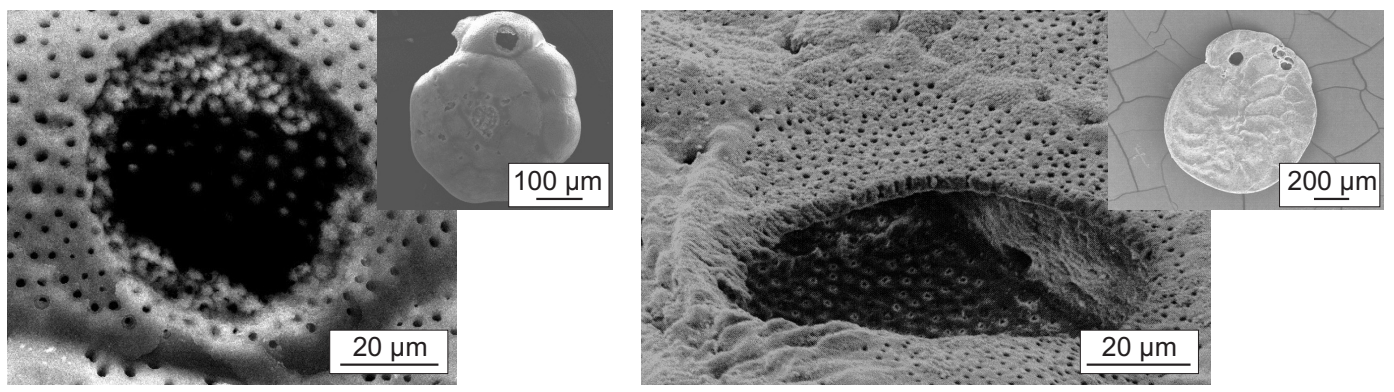

Fig. 3. Scanning electron microscope image of laser ablation craters in Ammonia (left) and Heterostegina (right). Insets depict the whole specimen. Scale bar is indicated in the lower right corner only for the magnified image.

\subsection{Partition coefficient of $\mathrm{Cu}-$ Ammonia tepida}

Two ablation profiles were obtained from two specimens of Ammonia tepida that grew new chambers at a low (0.20 $\mu \mathrm{mol} / \mathrm{l}) \mathrm{Cu}$-concentration (Fig. 4). Measurements indicate that the partition coefficient lies between 0.1 and 0.4 . In the right panel of Fig. 4, the same two measurements are depicted at the left end of the graph. Ratios for calcite formed at higher $(\mathrm{Cu} / \mathrm{Ca})_{\text {seawater }}$, indicated a partition coefficient between 0.1 and 0.4 .

\subsection{Partition coefficient of $\mathrm{Cu}-$ Heterostegina depressa}

Although individuals of Heterostegina did not survive the highest $\mathrm{Cu}$-levels, we obtained two ratios from specimens that added new chambers at a target concentration of $10 \mu \mathrm{mol} / \mathrm{l}$. From incubations with lower $\mathrm{Cu}$-concentrations, more specimens were available that grew new chambers that could be analyzed for $\mathrm{Cu}$-concentration (Fig. 5).

\section{Discussion}

Within the experimental and analytical error both species show a similar $(\mathrm{Cu} / \mathrm{Ca})_{\text {seawater }}$ to $(\mathrm{Cu} / \mathrm{Ca})_{\text {calcite }}$ relation, indicating a partition coefficient $\left(\mathrm{D}_{\mathrm{Cu}}\right)$ of $0.25 \pm 0.15$. No significant difference was observed in copper incorporation between Ammonia tepida and Heterostegina depressa, despite large differences in ecology and habitat. Some interspecimen variation in $\mathrm{Cu} / \mathrm{Ca}_{\text {calcite }}$ was observed in $H$. depressa grown at low $\mathrm{Cu}$-concentrations, in which rather large uncertainties in culture water $\mathrm{Cu}$-concentration (Fig. 5) resulted from changes in $\left[\mathrm{Cu}^{2+}\right]$ over time. Moreover, the alternative calibration method used for the thin-walled chambers of A. tepida (i.e. using a pressed calcite pellet and a lower ablation energy) increased the analytical uncertainty in the laser ablation-ICP-MS analyses (Fig. 5). Despite these errors, the calculated $\mathrm{D}_{\mathrm{Cu}}$ was not significantly dependent on either temperature or salinity.

\subsection{Experimental uncertainties}

The seawater $\mathrm{Cu}$-concentrations in most culture media increased during the incubation period (Table 1), however, 


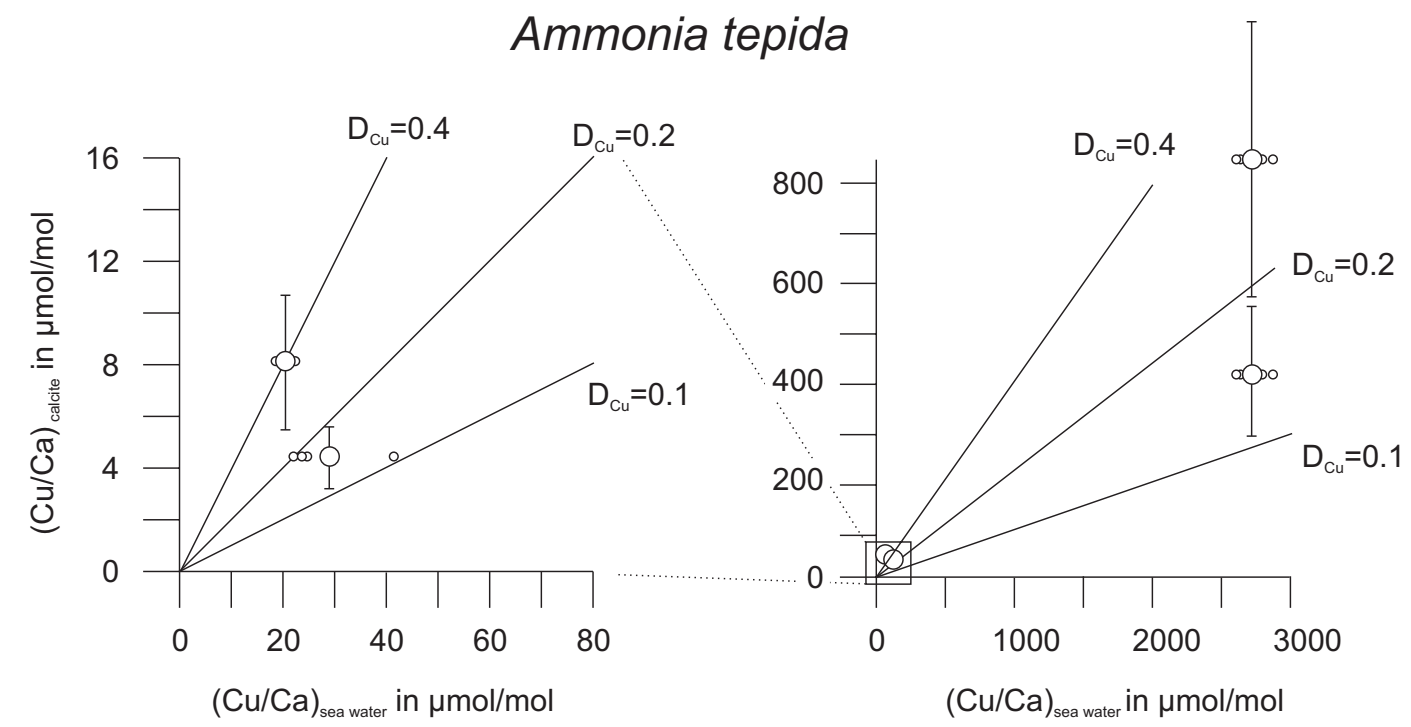

Fig. 4. $\mathrm{Cu} / \mathrm{Ca}$ ratios in Ammonia tepida test carbonate versus $\mathrm{Cu} / \mathrm{Ca}$ in sea water. Left graph is an enlargement of right one: small circles indicate the separate $[\mathrm{Cu}]_{\text {seawater }}$ measurements (replicate samples before and after the incubation period), large circles represent the average

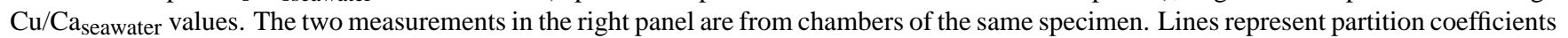
of $0.1,0.2$ and 0.4 .

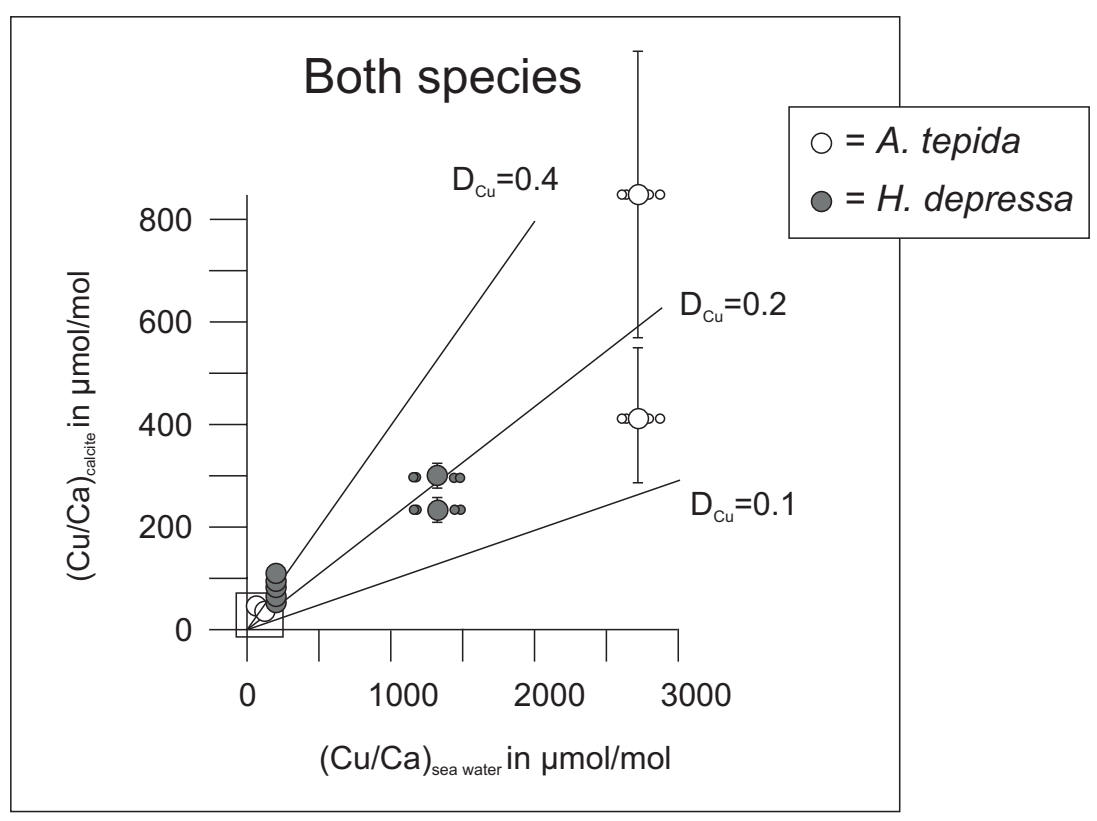

Fig. 5. Plot of $\mathrm{Cu} / \mathrm{Ca}$ ratios in foraminiferal calcite of the added chamber versus the $\mathrm{Cu} / \mathrm{Ca}$ of the sea water in which they were incubated. The two Heterostegina-measurements in the center of the graph represent two chambers of the same specimen. Lines indicate partition coefficients of $0.1,0.2$ and 0.4 .

there is no systematical difference in $\mathrm{Cu} / \mathrm{Ca}_{\text {seawater }}$ ratios before and after the two experiments. Therefore, analytical errors during ICP-MS or during subsampling of the culture vessels are unlikely to play an important role in this offset. Sorption of $\mathrm{Cu}$ onto organic matter in the culture media or onto the calcite of the foraminifera would have low- ered the $\mathrm{Cu}$-concentrations in the media, which happened in some cases, and therefore could have contributed to the differences in $\mathrm{Cu} / \mathrm{Ca}$ ratios. Alternatively, release of $\mathrm{Cu}$ by the culture vessels or trays could have increased seawater $\mathrm{Cu}-$ concentrations, although this is unlikely since the equipment used was new or cleaned prior to the experiment. Moreover, 
the control media (no $\mathrm{Cu}$ added) did not contain considerable amounts of $\mathrm{Cu}$, indicating that contamination by the materials used played a minor role. The foraminifera themselves are unlikely to have contained high concentrations of $\mathrm{Cu}$ at the start of the experiments since concentrations of this metal are low in natural seawater. Cu-pollution of seawater during subsampling for seawater $\mathrm{Cu}$-analyses may have caused an increase in $\mathrm{Cu}$-concentrations, although care was taken to avoid such contamination. Differences in seawater $\mathrm{Cu}$-concentrations before and after the incubation period are likely to be the result of a combination of the processes mentioned above.

The use of calcein in our experiments may have affected the uptake of $\mathrm{Cu}$, although it is suggested that the incorporation of trace elements do not seem to be affected by the presence of calcein (Hintz et al., 2004). Measured $\mathrm{Mg} / \mathrm{Ca}$ ratios in chambers that incorporated calcein were of the same order of magnitude as pre-existing chambers of the same specimens (data not published). This too suggests that the presence of calcein does not influence the uptake of trace elements.

The number of new chambers formed by the cultured foraminifera was generally low, especially at high $\mathrm{Cu}-$ concentrations (Table 4). The limited production of new calcite may indicate that the conditions during the experiments were not optimal for the foraminifera. The accumulation of waste products in the culture vessels, for example, was not monitored and may have changed the seawater chemistry. Increasing the seawater reservoir size may reduce the effect of such accumulations (see Hintz et al., 2004, 2006a, b). In addition, the micro-environments in which the specimens were kept and calcified, may have differed from natural conditions in other ways. The environmental stability in our set-up is not found in intertidal flats, nor was it possible for specimens of Ammonia tepida in these experiments to occupy dysoxic sediment layers, as regularly observed in field studies. Therefore, the results obtained in these experiments, may not be applicable for all environments in which the two species potentially calcify. Additional experiments, including anoxia, different $\mathrm{pH}$ 's, different light/dark regimes may thus be necessary to investigate the full array of environmental conditions under which foraminiferal calcite may be produced. Improving culturing setups and optimizing laboratory conditions is important and comparison of our results with those from optimized, future experiments is necessary to establish a more precise $\mathrm{D}_{\mathrm{Cu}}$ for foraminiferal calcite.

\section{2 $\mathrm{Cu}$ in the calcite lattice}

Crystalline $\mathrm{CuCO}_{3}$ does not exist, because the most common coordination of $\mathrm{Cu}$-carbonate complexes is distorted tetragonal pyramids or distorted octahedrons (Wells, 1984). These shapes do not allow precipitation of pure $\mathrm{CuCO}_{3}$ crystals and rather $\mathrm{Cu}_{2} \mathrm{CO}_{3}(\mathrm{OH})_{2}$ (malachite) will form. However, sorption studies have shown that at the calcite-water interface these so-called Jahn-Teller distortions can be overcome and a solid solution $\mathrm{Cu}_{\mathrm{x}} \mathrm{Ca}_{(1-\mathrm{x})} \mathrm{CO}_{3}$ forms (Schlosseler et al., 1999). It has been proposed that copper in calcite is present in clusters, based on studying the transformation of vaterite to calcite (Nassrallah-Aboukaiis et al., 1996, 1998). Recent XAFS work, however, has shown that this mechanism is not applicable to calcite surfaces (Elzinga and Reeder, 2002). This rather unusual complexation behavior would suggest that sorption and subsequent incorporation into the crystal lattice for copper is limited to part of the crystal surface only. This, in turn, would result in a lower partition coefficient for copper than expected based on its ionic radius only.

Contrary to these results, it has been shown that during inorganic coprecipitation experiments $\mathrm{Cu}$ is incorporated in calcite with a distribution coefficient $\left(\mathrm{K}_{\mathrm{Cu}}\right)$ of 23 and constant under a range of $\mathrm{Cu}$-concentrations (Kitano et al., 1980). In the initial stage of calcification, the $\mathrm{K}_{\mathrm{Cu}}$ can be even higher (40) probably due to the strong affinity of $\mathrm{Cu}(\mathrm{OH})_{2}$ for calcite surfaces (Franklin and Morse, 1982; Pickering, 1983; Papadopoulos and Rowell, 1989). This indicates that the Jahn-Teller distortions are easily overcome during calcification.

Generally, divalent cations with an ionic radius close to $\mathrm{Ca}(=1.0 \AA)$ have a partition coefficient in calcite close to 1 . Cd has an ionic radius of $0.95 \AA$ (Shannon, 1976) and is incorporated in both planktonic and benthic species with a D between 1 and 4 (Boyle, 1981, 1988; Havach et al., 2001; Maréchal-Abram et al., 2004), independent of temperature (Marchitto, 2004). Sr (ionic radius = 1.31 $\AA$ ) is incorporated in foraminiferal calcite with a $\mathrm{D}$ of $0.11-0.19$, measured in several planktonic genera (Bender et al., 1975) and 0.05-0.25 in Cibicidoides (Elderfield et al., 1996). Coretop studies on Cibicides and Uvigerina show that $\mathrm{Ba}(1.47 \AA)$ is incorporated with a partition coefficient of $0.3-0.4$ at $3^{\circ} \mathrm{C}$ (Lea and Boyle, 1989). In the planktonic genera Globorotalia and Globoquadrina, Ba is incorporated with a D of 0.19 (Lea and Boyle, 1991). $\mathrm{Cu}$ has an ionic radius close to $\mathrm{Mg}$ (0.73 and $0.72 \AA$, respectively), but the partition coefficient of $\mathrm{Mg}$ is much lower $\left(0.1-1 \times 10^{-3}\right.$; Bender et al., 1975; Delaney et al., 1985) than the measured $0.1-0.4$ for $\mathrm{Cu}$ (Fig. 7). The large difference between the foraminifer-mediated $\mathrm{Cu}$ incorporation and the inorganic incorporation of $\mathrm{Cu}$ in calcite indicates that much energy is spent on removal of $\mathrm{Cu}$ at the site of calcification.

\subsection{Biological control on $\mathrm{D}_{\mathrm{Cu}}$}

Since magnesium inhibits calcite growth (Berner, 1975; Mucci and Morse, 1983) and high levels of $\mathrm{Mg}$ are likely to be present in foraminiferal calcifying reservoirs, it is necessary for foraminifera to remove $\mathrm{Mg}$ before calcification. It has been suggested that foraminifera actively pump $\mathrm{Mg}$ from their calcifying reservoir in order to stimulate $\mathrm{CaCO}_{3}$ precipitation (Duckworth, 1977; Bentov and Erez, 2006). Usually, $\mathrm{Cu}$ is present only in very low concentrations in seawater 
and therefore no need exists to actively remove $\mathrm{Cu}$ from calcifying reservoirs, despite its ability to modify the crystalline structure of calcite. Although under high $\mathrm{Cu}$-concentrations it may be beneficial to remove $\mathrm{Cu}$ from calcifying reservoirs, apparently the foraminifera does not do so, as the $\mathrm{D}_{\mathrm{Cu}}$ is similar for high and low $\mathrm{Cu}$-concentrations. Alternatively, the concentrations used in our experiments may still be too low to seriously impede $\mathrm{CaCO}_{3}$ precipitation.

Another reason for active removal of trace elements from calcifying reservoirs is that these elements are necessary for cellular processes. Since $\mathrm{Cu}$ is known to play only minor roles in eukaryotic metabolic processes (Bruland et al., 1991; Sunda and Huntsman, 1995; Chang and Reinfelder, 2000), it is unlikely that the $\mathrm{D}_{\mathrm{Cu}}$ is affected by cellular needs. Organic compounds may increase $\mathrm{Mg}$ contents in foraminiferal calcite (Bentov and Erez, 2006). High concentrations of Mg at the primary organic membrane (Hemleben et al., 1986) may explain the observed intra-test variability of $\mathrm{Mg} / \mathrm{Ca}$ (e.g. Toyofuku and Kitazato, 2005). $\mathrm{Cu}$ also has a strong affinity for organic compounds (see below), so that the $\mathrm{D}_{\mathrm{Cu}}$ may be partly determined by the presence of organic compounds in the calcite.

Bresler and Yanko (1995) showed that some benthic, epiphytic foraminifera have tryptofan-containing proteins that can bind $\mathrm{Cu}^{2+}$ and prevent intracellular $\mathrm{Cu}$-concentrations from becoming harmful. When a significant part of the $\mathrm{Cu}^{2+}$ would have been immobilized by these $\mathrm{Cu}$-binding proteins this would also have lowered the $\mathrm{Cu}$ activity in the solution and thus $\mathrm{D}_{\mathrm{Cu}}$. Since we have not observed such a decrease, it is unlikely that such molecules play a major role in decreasing intracellular $\mathrm{Cu}$-concentrations.

Seawater $\mathrm{pH}$ is a potentially important modulator of trace metal uptake (Lea et al., 1999; Zeebe and Sanyal, 2002). To investigate the potential effect we compared species with and without symbionts. In the symbiont-bearing $H$. depressa the photosynthetic activity of the symbionts changes the local carbonate chemistry because $\mathrm{CO}_{2}$ is taken up and $\mathrm{pH}$ lowered during light conditions. However, the lack of any systematic offset in $\mathrm{Cu} / \mathrm{Ca}$ between the $H$. depressa and A. tep$i d a$ suggests no significant effect of $\mathrm{pH}$ on $\mathrm{Cu}$ incorporation. It may be, however, that difference in $\mathrm{pH}$ at the site of calcification between and within the species is partly responsible for the observed variation in $\mathrm{D}_{\mathrm{Cu}}$.

\subsection{Test deformation and mortality}

A number of studies over the last 20 years have attempted to correlate the number of deformed tests to environmental pollution (Alve, 1991; Elberling et al., 2003; Armynot du Châtelet et al., 2004). The empirical correlation between number of deformed tests and for instance heavy metal or hydrocarbon concentration levels was interpreted to signify a causal relationship. Results from such investigations are difficult to apply widely, since deformations in foraminifera take place easily in some groups (e.g. Mil- iolids and Discorinopsis), while in other taxa (e.g. within the familily Glaberatellidae) deformaties are rarely found (Arnold, 1954). Furthermore, in foraminiferal cultures that were exposed to oil pollution no increased test abnormalities were observed (Ernst et al., 2006). In addition, not a single deformed chamber alignment was observed in our experiments, despite the fact that $\mathrm{Cu}$-concentrations were occasionally well above levels found at even the most polluted sites. Although the limited number of observations does not allow a statistical evaluation, our results strongly suggest that high levels of $\mathrm{Cu}$ do not cause test deformities. This is also shown by Alve and Olsgard (1999), who found no test deformities in foraminifera living in seawater with high $\mathrm{Cu}$-concentrations.

Therefore, we think that relative abundances of deformed tests in fossil samples are not suitable to reconstruct past copper concentrations. Most likely other environmental factors, co-varying with environmental trace metal levels must have been responsible for the observed increase in test deformities. The complete absence of deformations in our experiments is in high contrast to the low but still detectable levels of natural occurring test deformities under environmental pristine conditions. This suggests that the protected environment of the culture trays may actually have shielded our foraminifera by providing them with a constant temperature, salinity and seawater chemistry in general.

In seawater with the highest concentration of $\mathrm{Cu}$ $(20 \mu \mathrm{mol} / \mathrm{l})$, none of the Heterostegina's survived and only one specimen grew new chambers when cultured at $10 \mu \mathrm{mol} / \mathrm{l}$. Since the growth or survival of Ammonia tepida did not appear to be hampered by high concentrations of $\mathrm{Cu}$, we hypothesize that either the symbionts of the tropical foraminifera are vulnerable to high $\mathrm{Cu}$-concentrations (Brandt et al., 1986), or that individuals of A. tepida are adapted to cope with (occasional) high levels of heavy metals.

\subsection{Application of $\mathrm{Cu} / \mathrm{Ca}$ ratios in foraminiferal calcite}

In order to quantify pollution levels, heavy metal concentrations are often analyzed using strong acid extractions and subsequent ICP-MS analyses of bulk sediment. Since heavily polluted sites are frequently characterized by high concentrations of (labile) organic matter, polluted sediments are often anoxic with high levels of sulphate reduction and associated production of free sulfide. These high sulfide-levels result in immobilization of heavy metals such as $\mathrm{Zn}, \mathrm{Cu}$, $\mathrm{Cd}$ and $\mathrm{Pb}$, which are precipitated as the highly insoluble minerals $\mathrm{PbS}, \mathrm{CuS}$ and $\mathrm{ZnS}$, or as co-precipitates in pyrite (Rashid and Leonard, 1973; Saxby, 1973; Huerta-Diaz and Morse, 1992). Because these metals are no longer bioavailable they do not reflect toxicity of the overlying water to, for instance, benthic biota. Actual analyses of the overlying water itself or organisms living in these waters would give a much more applicable concentration to assess pollution (Nelson and Donkin, 1985; Bryan and Langston, 1992). This 
becomes even more important when at a later stage organic loads decrease and/or the oxygen level increases, (e.g. after improved wastewater treatment). Under these conditions lower sedimentary trace metal levels could result in higher actual toxicity as these metals are remobilized by progressive re-oxidation of the sediment and escape to the overlying water (Petersen et al., 1997). Monitoring foraminiferal test $\mathrm{Cu} / \mathrm{Ca}$ ratios could be used to establish the bioavailable fraction of $\mathrm{Cu}$ and potentially also could record relatively short episodes with elevated bottom water $\mathrm{Cu}$-levels.

Sludge dump sites and associated elevated concentration levels of heavy metals are mostly limited to coastal and estuarine environments. These settings experience considerably varying seasonal and even daily temperatures and salinity levels. A significant impact of either temperature or salinity on partition coefficients would, therefore, render foraminiferal trace metal records useless for any reliable reconstruction and/or monitoring of such dump sites. Since the obtained $\mathrm{D}_{\mathrm{Cu}}$ is not markedly dependent on either temperature or salinity, foraminiferal $\mathrm{Cu} / \mathrm{Ca}$ ratios may be a powerful proxy for the quantitative reconstruction of past heavy metal pollution, even in highly variable environments.

\section{Conclusions}

Copper is incorporated into foraminiferal calcite with an estimated partition coefficient of $0.25 \pm 0.15$ with respect to seawater $\mathrm{Cu} / \mathrm{Ca}$ values. No effects on the $\mathrm{D}_{\mathrm{Cu}}$ of speciesspecific control or of temperature and salinity could be observed with the experimental setup used here. Additional experiments are needed to better constrain $\mathrm{D}_{\mathrm{Cu}}$ and unravel the effects of other likely important environmental factors such as temperature, salinity and seawater carbonate chemistry.

Acknowledgements. The authors thank M. Janse from Burger's Zoo and W. Renema from Naturalis for providing specimens of Heterostegina depressa. P. Kleingeld is acknowledged for his help with developing the culturing set-up. The laser ablation measurements were greatly aided by G. Nobbe. E. van Vilsteren and B. van Os provided help with the ICP-MS-analyses and discussion on seawater chemistry. Comments provided by E. Hathorne and two anonymous reviewers improved the text considerably. This research was sponsored by TNO-NITG, Utrecht. Support from the European Science Foundation (ESF) under the EUROCORESProgramme "EuroCLIMATE", through contract No. ERAS-CT-2003-980409 of the European Commission is acknowledged. NWO is acknowledged for supporting the Dutch partner in "PaleoSalt".

Edited by: J. Bijma

\section{References}

Alve, E.: Benthic foraminifera in sediment across cores reflecting heavy metal pollution in Sørfjord, western Norway, J. Foraminifer. Res., 21(1), 1-19, 1991.
Alve, E. and Olsgard, F.: Benthic foraminiferal colonization in experiments with copper contaminated sediment, J. Foraminifer. Res., 29(3), 186-195, 1999.

Armynot du Châtelet, E., Debenay, J.-P., and Soulard, R.: Foraminiferal proxies for pollution monitoring in moderately polluted harbors, Environ. Pollut., 127, 27-40, 2004.

Arnold, Z. M.: Discorinopsis aguayoi (Bermudez) and Discorinopsis vadecens Cushman and Bronnimann: A study of variation in cultures of living foraminifera, Contr. Cushman Found. Foraminifer. Res., 5(1), 4-13, 1954.

Bender, M. L., Lorens, R. B., and Williams, D. F.: Sodium, magnesium, and strontium in the tests of planktonic foraminifera, Micropaleontol., 21, 448-459, 1975.

Bentov, S. and Erez, J.: Impact of biomineralization processes on the $\mathrm{Mg}$ content of foraminiferal shells: A biological perspective, Geochem. Geophys. Geosyst., 7(1), Q01P08, doi:10.1029/2005GC001015, 2006.

Bernhard, J. M., Blanks, J. K., Hintz, C. J., and Chandler, G. T.: Use of fluorescent calcite marker calcein to label foraminiferal tests, J. Foraminifer. Res., 34(2), 96-101, 2004.

Berner, R. A.: The role of magnesium in the crystal growth of calcite and aragonite from seawater, Geochim. Cosmochim. Acta, 39(4), 489-504, 1975.

Bijma, J., Honisch, B., and Zeebe, R. E.: Impact of the ocean carbonate chemistry on living foraminiferal shell weight: Comment on "Carbonate ion concentration in glacial-age deep waters of the Caribbean Sea" by W. S. Broecker and E. Clark., Geochem. Geophys. Geosyst., 3(11), 1064, doi:10.1029/2002GC000388, 2002.

Borrego, J., López-González, N., and Carro, B.: Geochemical signature as paleoenvironmental markers in Holocene sediments of the Tinto River estuary (Southwestern Spain), Est. Coast. Shelf Sci., 61, 631-641, 2004.

Boyle, E. A.: Cadmium, zinc, copper, and barium in foraminifera tests, Earth Planet. Sci. Lett., 53, 11-35, 1981.

Boyle, E. A.: Cadmium: chemical tracer of deepwater paleoceanography, Paleoceanography, 3, 471-489, 1988.

Brandt, L. E., Sunda, W. G., and Guillard, R. R. L.: Reduction of marine phytoplankton reproduction rates by copper and cadmium, J. Exp. Mar. Biol. Ecol., 96, 225-250, 1986.

Bresler, V. and Yanko, V.: Chemical ecology: A new approach to the study of living benthic epiphytic foraminifera, J. Foraminifer Res., 25(3), 267-279, 1995.

Bruland, K. W., Donat, J. R., and Hutchins, D. A.: Interactive influences of bioactive trace metals on biological production in oceanic waters, Limnol. Oceanogr., 36(1), 1555-1577, 1991.

Bryan, G. W. and Langston, W. J.: Bioavailability, accumulation and effects of heavy metals in sediments with special reference to estuaries: A review, Environ. Pollut., 76(2), 89-131, 1992.

Chang, S. I. and Reinfelder, J. R.: Bioaccumulation, subcellular distribution, and trophic transfer of copper in a coastal marine diatom, Environ. Sci. Technol., 34, 4931-4935, 2000.

Delaney, M. L., Bé, A. W. H., and Boyle, E. A.: Li, Sr, Mg, and Na in foraminiferal calcite shells from laboratory culture, sediment traps, and sediment cores, Geochim. Cosmochim. Acta, 49(6), 1327-1341, 1985.

Duckworth, D. L.: Magnesium concentration in the tests of the planktonic foraminifer Globorotalia truncatulinoides, J. Foram. Res., 7(4), 304-312, 1977.

Elberling, B., Knudsen, K. L., Kristensen, P. H., and Asmund, G.: 
Applying foraminiferal stratigraphy as a biomarker for heavy metal contamination and mining impact in a fiord in west Greenland, Mar. Environ. Res., 55, 235-256, 2003.

Elderfield, H., Bertram, C. J., and Erez, J.: A biomineralization model for the incorporation of trace elements into foraminiferal calcite, Earth Planet. Sci. Lett., 142, 409-423, 1996.

Ellison, R. L., Broome, R., and Oglivie, R.: Foraminiferal response to trace metal contamination in the Patapsco River and Baltimore harbour, Maryland, Mar. Pollut. Bull., 17(9), 419-423, 1986.

Elzinga, E. J. and Reeder, R. J.: X-ray absorption spectroscopy study of $\mathrm{Cu}^{2+}$ and $\mathrm{Zn}^{2+}$ adsorption complexes at the calcite surface: Implications for site-specific metal incorporation preferences during calcite crystal growth, Geochim. Cosmochim. Acta, 66(22), 3943-3954, 2002.

Eriksen, R. S., Mackey, D. J., Van Dam, R., and Nowak, B.: Copper speciation and toxicity in Macquarie Harbour, Tasmania: an investigation using a copper ion selective electrode, Mare Chem., 74, 99-113, 2001.

Ernst, S. R., Morvan, J., Geslin, E., Le Bihan, A., and Jorissen, F. J.: Benthic foraminiferal response to experimentally induced Erika oil pollution, Mar. Micropal., 61, 76-93, 2006.

Ferraro, L., Sprovieri, M., Alberico, I., Lirer, F., Prevedello, L., and Marsella, E.: Benthic foraminifera and heavy metals distribution: A case study from the Naples harbour (Tyrrhenean Sea, Southern Italy), Environ. Pollut., 142, 274-287, 2006.

Franklin, M. L. and Morse, J. W.: The interaction of copper with the surface of calcite, Ocean Sci. Eng., 7, 147-174, 1982.

Gaffey, S. J. and Brönnimann, C. E.: Effects of bleaching on organic and mineral phases in biogenic carbonates, Journal of Sediment. Petrol., 63, 752-754, 1993.

Geslin, E., Debenay, J.-P., Duleba, W., and Bonetti, C.: Morphological abnormalities of foraminiferal tests in Brazilian environments: comparison between polluted and non-polluted areas, Mar. Micropaleontol., 45, 151-168, 2002.

Hallock, P., Lidz, B. H., Cockey-Burkhard, E. M., and Donnelly, K. B.: Foraminifera as bioindicators in coral reef assessment and monitoring: the FORAM index, Environ. Monit. and Assess., 83(1-3), 221-238, 2003.

Havach, S. M., Thomas Chandler, G., Wilson-Finelli, A., and Shaw, T. J.: Experimental determination of trace element partition coefficients in cultured benthic foraminifera, Geochim. Cosmochim. Acta, 65(8), 1277-1283, 2001.

Hayward, B. W., Holzmann, M., Grenfell, H. R., Pawlowski, J., and Triggs, C. M.: Morphological distinction of molecular types in Ammonia - towards a taxonomic revision of the world's most commonly misidentified foraminifera, Mar. Micropaleontol., 50, 237-271, 2004.

Hemleben, C. H., Anderson, O. R., Berthold, W., and Spindler, M.: Calcification and chamber formation in Foraminifera- a brief overview, in: Biomineralization in lower plants and animals, Systematics Association Special Volume 30, edited by: Leadbeater, B. S. C. and Riding, R., Clarendon Press, Oxford (for the Systematics Association), p 237-249, 1986.

Hintz, C. J., Chandler, G. T., Bernhard, J. M., McCorkle, D. C., Havach, S. M., Blanks, J. K., and Shaw, T. J.: A physicochemically constrained seawater culturing system for production of benthic foraminifera, Limnol. Oceanogr-Meth., 2, 160-170, 2004.

Hintz, C. J., Shaw, T. J., Chandler, G. T., Bernhard, J. M., Mc-
Corkle, D. C., and Blanks, J. K.: Trace/ minor element:calcium ratios in cultured benthic foraminifera. Part I: Inter-species and inter-individual variability, Geochim. Cosmochim. Acta, 70(8), 1952-1963, 2006a.

Hintz, C. J., Shaw, T. J., Bernhard, J. M., Chandler, G. T., McCorkle, D. C., and Blanks, J. K.: Trace/ minor element:calcium ratios in cultured benthic foraminifera. Part II: Ontogenetic variation, Geochim. Cosmochim. Acta, 70(8), 1964-1976, $2006 \mathrm{~b}$.

Huerta-Diaz, M. A. and Morse, J. W.: Pyritization of trace metals in anoxic marine sediments, Geochim. Cosmochim. Acta, 56(7), 2681-2702, 1992.

Kitano, Y., Okumura, M., and Idogaki, M.: Abnormal behaviors of copper (II) and zinc ions in parent solution at the early stage of calcite formation, Geochem. J., 14, 167-175, 1980.

Koide, M., Lee, D. S., and Goldberg, E. D.: Metal and transuranic records in mussel shells, byssal threads and tissues, Estuar. Coast. Shelf Sci., 15, 679-695, 1982.

Lea, D. W. and Boyle, E. A.: Ba content of benthic foraminifera controlled by bottom water composition, Nature, 338, 751-753, 1989.

Lea, D. W. and Boyle, E. A.: Ba in planktonic foraminifera, Geochim. Cosmochim. Acta, 55, 3321-3331, 1991.

Lea, D. W., Mashiotta, T. A., and Spero, H. J.: Controls on magnesium and strontium uptake in planktonic foraminifera determined by live culturing, Geochim. Cosmochim. Acta, 63(16), 23692379, 1999.

Le Cadre, V. and Debenay, J.-P.: Morphological and cytological responses of Ammonia (foraminifera) to copper contamination: Implications for the use of foraminifera as bioindicators of pollution, Environ. Pollut., 143, 304-317, 2006.

Lewis, E. and Wallace, D. W. R.: Program Developed for CO2 System Calculations, ORNL/CDIAC-105, Carbon Dioxide Information Analysis Center, Oak Ridge National Laboratory, U.S. Department of Energy, Oak Ridge, Tennessee, 1998.

Lu, Y. F. and Allen, H. E.: Characterization of copper complexation with natural dissolved organic matter (DOM) - link to acidic moieties of DOM and competition by $\mathrm{Ca}$ and $\mathrm{Mg}$, Water Res., 36, 5083-5101, 2002.

Mackey, D. J. and Zirino, A.: Comments on trace metal speciation in seawater or do "onions" grow in the sea?, Anal. Chim. Acta, 284, 635-647, 1994.

Mason, P. R. D. and Kraan, W. J.: Attenuation of spectral interferences of during laser ablation inductively coupled plasma mass spectrometry (LA-ICP-MS) using an rf only collision and reaction cell, J. Anal. At. Spectrom., 17, 858-867, 2002.

Marchitto, T. M.: Lack of a significant temperature influence on the incorporation of $\mathrm{Cd}$ into benthic foraminiferal tests, Geochem. Geophys. Geosyst., 5(10), Q10D11, doi:10.1029/2004GC000753, 2004.

Maréchal-Abram, N., Debenay, J.-P., Kitazato, H., and Wada, H.: Cadmium partition coefficients of cultured benthic foraminifera Ammona beccarii, Geochem. J., 38(3), 271-283, 2004.

Morse, J. W. and Bender, M. L.: Partition coefficients in calcite: examination of factors influencing the validity of experimental results and their application to natural systems, Chem. Geol., 82, 265-277, 1990.

Mucci, A.: The solubility of calcite and aragonite in seawater at various salinities, temperatures, and one atmosphere total pressure, Am. J. Sci., 283, 780-799, 1983. 
Mucci, A. and Morse, J. W.: The incorporation of $\mathrm{Mg}^{2+}$ and $\mathrm{Sr}^{2+}$ into calcite overgrowths: influences of growth rate and solution composition, Geochim. Cosmochim. Acta, 47(2), 217-233, 1983.

Nassrallah-Aboukaïs, N., Boughriet, A., Fischer, J. C., Wartel, M., Langelin, H. R., and Aboukaïs, A.: Electron paramagnetic resonance (EPR) study of $\mathrm{Cu}^{2+}$ and $\mathrm{Mn}^{2+}$ ions interacting as probes with calciumcarbonate during the transformation of vaterite into cubic calcite, J. Chem. Soc. Lond. Faraday Trans., 92, 32113216, 1996.

Nassrallah-Aboukaïs, N., Boughriet, A., Laureyns, J., Aboukaïs, A., Fischer, J. C., Langelin, H. R., and Wartel, M.: Transformations of vaterite into cubic calcite in the presence of $\mathrm{Cu}(\mathrm{II})$ species, Chem. Mater., 10, 238-243, 1998.

Nelson, A. and Donkin, P.: Process of bioaccumulation: The importance of chemical speciation, Mar. Pol. Bull., 16(4), 164-169, 1985.

Nürnberg, D., Bijma, J., and Hemleben, C.: Assessing the reliability of magnesium in foraminiferal calcite as a proxy for water mass temperatures, Geochim. Cosmochim. Acta, 60(5), 803814, 1996

Parkhurst, D. L. and Appelo, C. A. J.: User's guide to PHREEQC (Version 2) - A computer program for speciation, batch-reaction, one-dimensional transport, and inverse geochemical calculations: U.S. Geological Survey Water-Resources Investigations Report, 99-4259, 1999.

Papadopoulos, P. and Rowell, D. L.: The reactions of copper and zinc 5 with calcium carbonate surfaces, J. Soil Sci., 40, 39-48, 1989.

Pearce, N. J. G., Perkins, W. T., Westgate, J. A., Gorton, M. P., Jackson, S. E., Neil, C. R., and Chenery, S. P.: A compilation of new and published major and trace element data for NIST SRM 610 and NIST SRM 612 glass reference materials, Geost. Newslett., 21(1), 115-144, 1997.

Petersen, W., Willer, E., and Willamowski, C.: Remobilization of trace elements from polluted anoxic sediments after resuspension in oxic waters, Water Air Soil Poll., 99(1-4), 515-522, 1997.

Pickering, W. F.: Extraction of copper, lead, zinc and cadmium ions sorbed on calcium carbonate, Water, Air, Soil Pollut., 20, 299309, 1983

Rashid, M. A. and Leonard, J. D.: Modifications in the solubility and precipitation behavior of various metals as a result of their interaction with sedimentary humic acid, Chem. Geol., 22(2), 89-97, 1973.

Rathburn, A. E. and DeDeckker, P.: Magnesium and strontium compositions of recent benthic foraminifera from the Coral Sea, Australia and Prydz Bay, Antarctica, Mar. Micropaleontol., 32, 231248, 1997.

Reichart, G. J., Jorissen, F. J., Anschutz, P., and Mason, P. R. D.: Single foraminiferal test chemistry, Geology, 31(4), 335-358, 2003.
Rosenthal, Y., Boyle, E. A., and Slowley, N.: Temperature control on the incorporation of magnesium, strontium, fluorine, and cadmium into benthic foraminiferal shells from Little Bahama Bank: prospects for thermocline paleoceanography, Geochim. Cosmochim. Acta, 61(17), 3633-3643, 1997.

Ruiz, F., González-Regalado, M. L., Borrego, J., Abad, M., and Pendón, J. G.: Ostracoda and foraminifera as short-term tracers of environmental changes in very polluted areas: the Odiel estuary (SW Spain), Environ. Pollut., 129, 49-61, 2004.

Sáinz, A. and Ruiz, F.: Influence of the very polluted inputs of the Tinto-Odiel system on the adjacent littoral sediments of southwestern Spain: A statistical approach, Chemosphere, 62, 16121622, 2006.

Samir, A. M. and El-Din, A. B.: Benthic foraminiferal assemblages and morphological abnormalities as pollution proxies in two Egyptian basins, Mar. Micropaleontol., 41, 193-227, 2001.

Saxby, J. D.: Diagenesis of metal-organic complexes in sediments: formation of metal sulphides from cystine complexes, Chem. Geol., 12(4), 241-248, 1973.

Segev, E. and Erez, J.: Effect of $\mathrm{Mg} / \mathrm{Ca}$ ratio in seawater on shell composition in shallow benthic foraminifera, Geochem. Geophys. Geosyst., 7(2), Q02P09, doi:10.1029/2005GC000969, 2006.

Shannon, R. D.: Revised effective ionic radii and systematic studies of interatomic distances in halides and chalcogenides, Acta Crystallogr. A, 32, 751-767, 1976.

Sunda, W. G. and Huntsman, S. A.: Regulation of copper concentration in the oceanic nutricline by phytoplankton uptake and regeneration cycles, Limnol. Oceanogr., 40(1), 132-137, 1995.

Toyofuku, T., Kitazato, H., Kawahata, H., Tsuchiya, M., and Nohara, M.: Evaluation of $\mathrm{Mg} / \mathrm{Ca}$ thermometry in foraminifera: Comparison of experimental results and measurements in nature, Paleoceanography, 15(4), 456-464, 2000.

Toyofuku, T. and Kitazato, H.: Micromapping of $\mathrm{Mg} / \mathrm{Ca}$ values in cultured specimens of the high magnesium benthic foraminifera, Geochem. Geophys. Geosyst., 6(11), Q11P05, doi:10.1029/2005GC000961, 2005.

Ueno, K., Imamura, T., and Cheng, K. L.: Handbook of organic analytical reagents, 2nd ed. CRC Publishers, 1992.

Wells, A. F.: Structural inorganic chemistry, 5th ed, Clarendon, 1984.

Zeebe, R. E. and Sanyal, A.: Comparison of potential strategies of planktonic foraminifera for house building: $\mathrm{Mg}^{2+}$ or $\mathrm{H}^{+}$removal?, Geochim. Cosmochim. Acta, 66(7), 1159-1169, 2002.

Zeebe, R. E. and Wolf-Gladrow, D.: CO2 in seawater: Equilibrium, kinetics and isotopes, Elsevier Oceanographic Series, Amsterdam, 2001.

Zirino, A. and Yamamoto, S.: A pH-dependent model for the chemical speciation of copper, zinc, cadmium, and lead in seawater, Limnol. Oceanogr., 17(5), 661-671, 1972. 